\title{
The Matthean characterisation of Jesus by God the Father
}

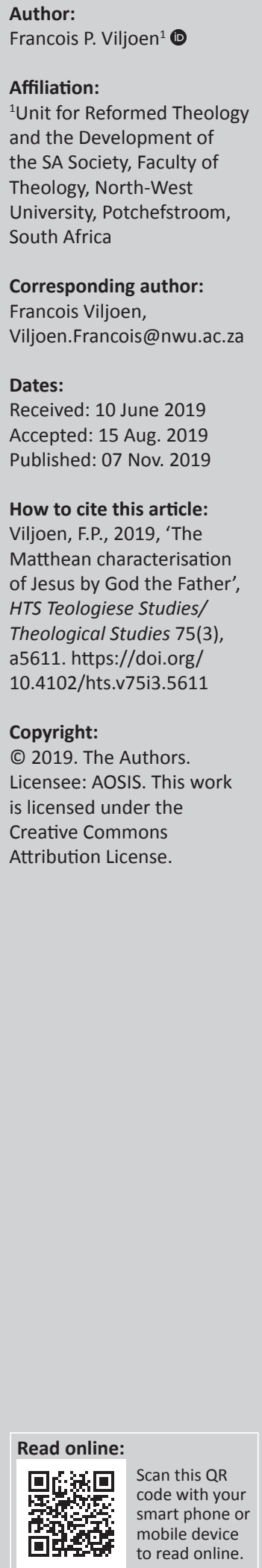

Author:

Affiliation:

Unit for Reformed Theology

Theology, North-West University, Potchefstroom

Corresponding author:

Francois Viljoen,

Dates:

Published: 07 Nov. 2019

How to cite this article: Viljoen, F.P., 2019, 'The of Jesus by God the Father', HTS Teologiese Studies/

Licensee: AOSIS. This work

is licensed under the

Creative Commons
This article uses a narrative analysis to contribute to the discourse on the characterisation of Jesus in the Matthean Gospel. Characterisation can be achieved in various ways. Much is revealed about characters through their actions and words, and how other role-players in the text respond to them. Sometimes there is a narrator who tells the reader about a character. The kind of character depends on the traits or personal qualities of that character and how that character performs during specific incidents. Along with God himself, Jesus forms the principal character in the First Gospel. His teachings and actions are central to the text and the actions of other characters are directed towards him. The article focuses on one aspect of characterisation, namely, on what characters say about Jesus. Such words can come from supporters or antagonists. The article concentrates on what God the Father says in support of Jesus. The Father's point of view is normative in this narrative. The evangelist utilises the utterances of God the Father as a narrative strategy to gradually assure the prominence and authority of the character of Jesus. Matthew's narrative clearly recounts Jesus' authority - an authority that comes from God and not only points towards him but also finally becomes his own. The Father attests that Jesus is greater and more authoritative than any previous messenger of God. It is Jesus who ultimately states that all authority has been bestowed upon him and therefore he can send out the disciples with his Great Commission. God's heavenly voice expresses the significant status of Jesus as the main character and exposes the malignity of his antagonists.

Keywords: narrative criticism; characterisation; Jesus; father; beloved son; Matthew.

\section{Introduction}

Reading Gospels as narratives ${ }^{1}$ mainly involves two aspects. The first aspect is to study the content of the narrative, in other words, what is told, the 'story'. The second aspect is to investigate how it is told and which rhetorical techniques are employed in the 'discourse' (Carter 1998:4-6; Kingsbury 1986:2). ${ }^{2}$ Simply put, the meaning of the narrative is the story and how this meaning is created is the discourse.

The 'story' of a narrative includes events, setting and characters (Kingsbury 1986:9; Powell 2009:4552). Authors bring characters ${ }^{3}$ to life by way of characterisation (Anderson 1994:78; Powell 1990:51; Tolmie 1999:41). Characterisation can take place by letting the characters act and speak by themselves, or by letting other characters talk to or about them, or react towards them. The author can give his own testimony of the character, as the Gospel of Matthew indeed does in the genealogy of Jesus (Mt 1:1-17), or can make use of a narrator who would tell the reader about a character (Anderson 1994:78-80; Bauer 1992:357). The kind of character depends on the traits or personal qualities of that character (Powell 2009:48). The individual status of a character is defined in terms of its relation to the main and other characters. Characters are involved in the incidents that are narrated, and they are characterised by their conduct during such events. Features of a character should be interpreted in terms of the specific incident and the context of the incident (Edwards 1997:13; Tolmie 1999:42).

A variety of characters feature in Matthew's Gospel. Characters can consist of individuals, such as God the Father, Jesus, the Holy Spirit, an angel or John the Baptist; or character groups, such as

1.This literary paradigm in Gospel studies should not invalidate historical and theological questions about the text (Hays 2013:17: Powel $1990: 98,2009: 44)$. The narrative worlds of the Gospels are related in various ways to both the world of Jesus and the social world of 1990:98, 2009:44). The narrative worlds
the evangelist (Culpepper 1984:472).

2.Chatman (1978:3) defines the plot as the 'story as discoursed' and Egan (1978:470) explains that 'a plot is a series of rules that determines and sequences events to cause affective response'. Genette defined the difference between a 'story' and a 'plot' in Discours du récit (1980). The 'story' [histoire] refers to the chronological sequence of events, and 'plot' refers to the way these events are presented in the narrative. When the events selected from the lives of people in certain times and places are combined into a series, a plot develops and the story becomes a narrative discourse [récit]. See Viljoen (2018) for a complete discussion on reading Matthew as a historical narrative.

3.A character is a paradigm of constructed traits that a reader attaches to a name (Burnett 1993:16; Powell 2009:49).

Note: The collection entitled 'Eben Scheffler Festschrift', sub-edited by Jurie H. le Roux (University of Pretoria) and Christo Lombaard (University of South Africa). 
the wise men, the disciples, Moses and Elijah, Jewish leaders or the crowds. Characters can be supernatural, human and even anthropomorphic beings, like the donkey that carried Jesus into Jerusalem. Along with God himself, Jesus is the principal character, the protagonist, ${ }^{4}$ in the narrative of the Gospel. There are only a few 'scenes' where he is not personally present. However, all scenes are related to Jesus. His teachings and actions are in the spotlight and the actions of other characters all pertain to him (Bauer 1992:357; Powell 1990:54; Weren 2014:12). God commissions him to assume the role of Redeemer 'because He will save his people from their sins' (Mt 1:21).

This article investigates one aspect of the characterisation of the Matthean Jesus, namely, what God the Father says in support of Jesus. ${ }^{5}$ The aim of the article is to demonstrate how the evangelist utilises God's words to attest that Jesus is greater and more authoritative than any previous messenger of God.

\section{The voice of God on two occasions}

As mentioned before, God is the main agent behind the narrative of Matthew. His point of view is normative (Carter 1998:8). ${ }^{6}$ He is the main character. However, he is invisible,

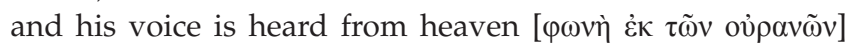
only twice. He has one line of direct discourse in the entire Gospel, and it is repeated with slight variations which echo Psalm 2:7 and Isaiah 42:1. When God speaks, he speaks of Jesus who forms the focus of attention. The first time he speaks is when Jesus is baptised (Mt 3:17), and the second time is when Jesus is transfigured (Mt 17:5). Parallels can be identified between these two scenes, as shown in Table 1 (based on Talbert 2010:58).

In the first scene, the voice of God is supported by the vision of the Holy Spirit, and in the second scene it is supported by Moses and Elijah. In both events, the interjection 'and behold' highlights the significance of the spoken words. In both cases, the invisible God speaks from the heavens. With Jesus' transfiguration, God repeats his words with Jesus' baptism, but adds 'listen to him'.

\section{God's declaration at the Baptism of Jesus}

God's voice is first mentioned in the scene where Jesus is baptised (Mt 3:13-17), where he testifies about Jesus.

\section{John as witness of God's declaration}

In this scene, the character of John is depicted as a type of Elijah (cf. 2 Ki 1:8; Zch 13:4), although he is not identified as

4.Greimas ([1966] 1983:174-185; 192-212) distinguished the actants in the narrative texts of the Gospels as the protagonist (the principal character or subject), the supporters or helpers (assist the protagonist), the object(s) (the persons, the acts and values of the protagonist are directed at) and the antagonists or opponents (those who oppose the efforts of the protagonist, like the Pharisees and scribes). The plot develops as a result of the interaction between the characters.

5.Besides God the Father, as series of other characters in the narrative witness in support of Jesus, for example, the Holy Spirit, angels, the wise men, John the Baptist and his disciples.

6.While God's view is normative in the narrative, he is opposed by the devil.
TABLE 1: Parallels between Jesus' baptism and his transfiguration.

\begin{tabular}{|c|c|c|}
\hline Baptism & Parallel & Transfiguration \\
\hline 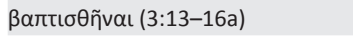 & Setting & 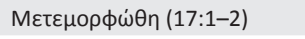 \\
\hline kai íઠoù (3:16b) & And behold & kai i̇ooù (17:3a) \\
\hline 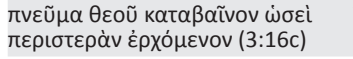 & Vision & 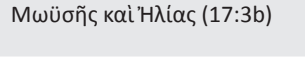 \\
\hline 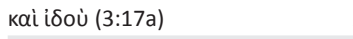 & And behold & kaì iઠooù (17:5b) \\
\hline 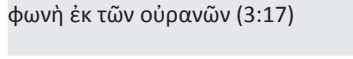 & $\begin{array}{l}\text { Voice from the } \\
\text { heavens }\end{array}$ & 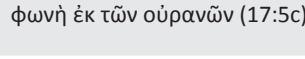 \\
\hline 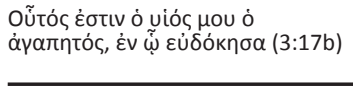 & God's words & 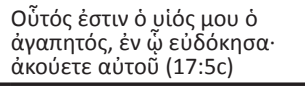 \\
\hline
\end{tabular}

such until Matthew 11:14. As character supporting Jesus, he is the one who has to prepare the way for the Lord (Mt 3:3) and the one who is expecting the One to come (Mt 3:11). In the Dialogue with Trypho (Dial 8.4), Justin Martin sheds light on this role of John ${ }^{7}$ (Talbert 2010:58). In this dialogue, the Jew Trypho rejects Justin's suggestion that he should convert to Christianity, and in defence says that the Messiah would remain unknown and powerless until Elijah has come to anoint him and to make him known to all. According to Trypho, Elijah has to anoint the Messiah first (Dial 49.1). But this Jewish expectation was surpassed when Jesus was anointed by the Holy Spirit, while John fulfilled his role as Elijah by announcing Jesus as the Messiah. With this vision and voice from heaven, the baptiser could witness the coming of the expected One. Together, John and Jesus could testify that God himself had declared from heaven that Jesus was his own son.

John performs his mission to prepare the way for the One to come. He therefore warns the people to get their lives in order, ' $[r]$ epent, for the kingdom of heaven is near' (Mt 3:2). Later on Jesus would announce the same message (Mt 4:17). While Jewish people in Palestine expected a time of judgement against wicked other people and the deliverance of themselves (Keener 1999:128), John challenges their self-assurance. John warns that the coming judge is incomparably powerful and that he is unworthy to even be the judge's slave. John compares the impending judgement of the One to come with images of a harvest and eternal destructive fire.

As the impending Jesus is baptised to ' $\pi \lambda \eta \rho \tilde{\sigma} \sigma \alpha \iota \pi \tilde{\alpha} \sigma \alpha \nu$

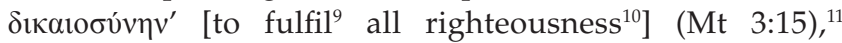

7.The Dialogue with Trypho is a 2 nd-century Christian apologetic text, documenting
the attempts by Justin Martyr to prove from Scripture that Jesus was the Jewish
Messiah. The Dialogue entails an intellectual conversation between Justin and
Trypho. Justin tries to convert Trypho to Christianity, which results in an animated
debate where Trypho criticises Christians on a number of grounds, and Justin
provides answers to each point of criticism, inter alia, on the identity of Jesus as the
expected Messiah (Allert 2002). 8.Deuteronomy 19:15 states the need for two witnesses.

9.France (1998:167) labels fulfilment as 'the special trademark' of this Gospel. Matthew thus claims his community to be heir to a great movement. While other New Testament writers quoted a few obvious texts as fulfilled in Jesus, Matthew explored this motif extensively (Davies \& Allison 2004a:211; Menken 2004:3; Versteeg 1992:23)

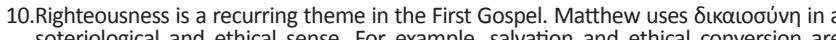
soteriological and ethical sense. For example, salvation and ethical conversion are symbolically effected through baptism. Through his baptism, Jesus fulfilled al

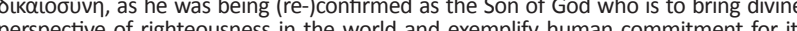
perspective of righteousness in the world and exemplify human commitment for it in his teaching and conduct. The Matthean community should do the same.

11.The Wisdom of Solomon 1:1-15 states that the fulfilment of all righteousness is what is required of a true king: '[l]ove righteousness, you rulers of the earth, think of the Lord with uprightness, and seek Him with sincerity of heart ...' 
Matthew 3:13-17 recounts the ceremony Jewish kings and other ancient kings had to partake in before they could speak or act as royal figures. It entailed the ritual of purification (baptism), followed by anointment (by God's Spirit) (Witherington III 2006:81). In Jewish expectation, it would be the special task of the Messiah to fulfil the will of $\operatorname{God}^{12}$ (e.g. Jr 23:5-6, 33:15; Zch 9:9) (Luz 2007:144). Here Jesus recognised the will of God and submitted himself to this rite of purification, after which he would publically be proclaimed as the royal Son of God. Consequently, he could take up the royal mantle and do the duties of a royal and divine Son of God, both as judge and as saviour. Jesus submitted himself to doing God's righteous and loving will for humanity to be their saviour according to God's salvific plan (Powell 1992:199; Witherington III 2006:85). He knew the will of the Father and obeyed it to the letter.

However, Jesus was not baptised because he was a sinner requiring purification, but to realise these Scriptural hopes (Davies \& Allison 2004a:326). In a traditional culture of honour and shame, Jesus relinquished his honour and embraced shame as he accepted baptism from a person of lower status. John recognised the greater status as he previously had witnessed to a mightier one whose sandals he was not fit to carry. While John baptised with water of repentance, Jesus would baptise with the Holy Spirit and with fire (Mt 3:11-12). He therefore objected to baptising Jesus (Keener 1999:131). With his insistence to be baptised, Jesus vicariously embraces humiliation on behalf of those the Father has called him to identify with.

\section{Significant signs}

After being baptised, Matthew and Mark mention that Jesus emerged from the water, while Luke mentions that Jesus was praying. ${ }^{13}$ In Judaism, creation was depicted as emergence from a watery chaos (Gn 1:3; Is 43:16-20). This scene in Matthew and Mark hints at a new creation of Israel. In Jewish thought, motifs of creation and exodus are intertwined with eschatological expectations. In this scene, Jesus repeats the experience of Israel wandering in the desert. As Israel came out of the water and entered the desert, so does Jesus come out of the water and enter the desert to suffer temptation (Davies \& Allison 2004a:328, 345), inaugurating a new beginning.

When he emerged from the water, two significant signs followed. The heavens opened and a dove descended upon Jesus (Table 2).

The onlookers of then would have been able to interpret the significance of these signs. ${ }^{14}$ Jews would have recalled passages like Isaiah 64:1 (LXX Is 63:19) ${ }^{15}$ and

12.In Matthew 5:20, the followers of Jesus are said to exceed the scribes and Pharisees in righteousness by completely submitting themselves to the will of God. What believers are called to do is fulfilled by Jesus.

13. Luke places special emphasis on the prayer life of Jesus and his teachings on prayer.

14.Several ancient authors have noted that when gods gave testimony on matters, their voices were confirmed by visions from the heavens (Talbert 2010:57).

15.'You would rend the heavens and come down ...' (Is 64:1).
TABLE 2: Signs when Jesus emerged from the water

\begin{tabular}{|c|c|c|}
\hline Matthew 3:16 & Mark 1:9-10 & Luke 3:21-22 \\
\hline 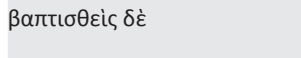 & 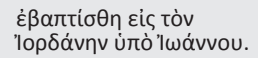 & 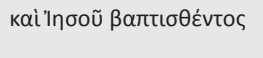 \\
\hline 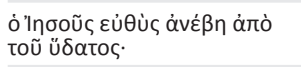 & 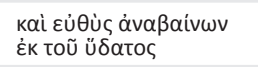 & 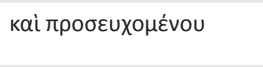 \\
\hline 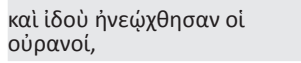 & 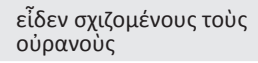 & 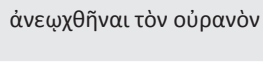 \\
\hline 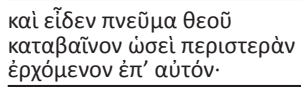 & 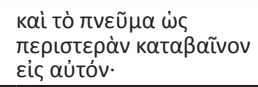 & 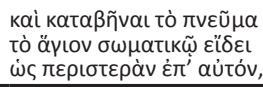 \\
\hline
\end{tabular}

Ezekiel $1: 1^{16}$ in which expectations of future deliverance from above were linked with the opening of heavens ${ }^{17}$ : ' $t$ t]his expectation is supported by the sign of the descending dove. This vision reminds of the Spirit of God hovering over the waters with creation' (Gn 1:2). The dove that appeared after the flood, heralding the new beginning in the days of Noah (Gn 8:8-12), probably forms the most appropriate background to this sign (Keener 1999:132). ${ }^{18}$

\section{God's voice from heaven}

After Jesus' public act of humility with his insistence on being baptised, God publically announces Jesus as his own son. God's voice brings all the previous testimonies of Jesus to a climax. Jesus is inaugurated at the beginning of his public ministry with this voice from heaven (Table 3).

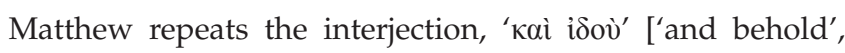
previously in Mt 3:17a], to highlight the significance of the voice from heaven, which forms the high point of the baptism scene. Similar to the other Synoptics, Matthew depicts God as an invisible divine speaker whose voice speaks directly from heaven.

Heavenly voices frequently occur in the Old Testament (e.g. Gn 21:17, 22:11, 15; Ex 19:19; Dt 4:10-12, etc.), the New Testament (e.g. Jn 12:28; Ac 9:4, 10:13-15, 11:7-9; 2 Pt 1:1:18) and Jewish texts (e.g. Josephus, Ant 13.283; 2 Bar 13:1, 22:1) that refer to God who speaks. ${ }^{19}$ This voice of God confirms three other voices that attested to the identity of Jesus: firstly, the angel that appeared in a dream to Joseph (Mt 1:20-21); secondly, the Scriptures, as Matthew frequently mentions the fulfilment of Scriptures in the person and conduct of Jesus (e.g. Mt 1:22, 2:15); and thirdly, John calling out in the wilderness, ' $r$ lepent, for the kingdom of heaven is near ...' (Mt 3:1-12) (Keener 1999:134).

The heavenly voice announces the sonship of Jesus. As Son of God, he experiences a relationship with God that is unique. While in Mark 1:11 and in Luke 3:22 the voice from heaven

16.The evangelist almost quotes word for word the introduction to the throne-chariot vision in Ezekiel: ' $[t]$ he heavens were opened and I saw visions of God' (Ezk 1:1).

17. Even the Aeneis of Vergilius 9:20-21 mentions the opening of heavens for the gods to speak.

18.Cicero (Top. 20.76-77) refers to the flight of birds along with omens from the gods. The philosopher Pythagoras teaches his disciples on bird omens and regards birds as messengers from the gods sent to those whom the gods truly love (Lamblichus, Vit. Pythagoras. 6.1).
Vithes

19.Some rabbinic sources, however, link voices from heaven to bat qôl as inferior substitutes to the Holy Spirit (t. Sota 13.2; b. Yoma 9b). 
TABLE 3: The voice from heaven.

\begin{tabular}{|c|c|c|}
\hline Matthew 3:17 & Mark 1:11 & Luke 3:22 \\
\hline 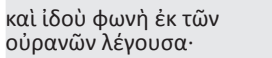 & 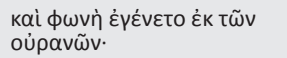 & 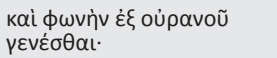 \\
\hline 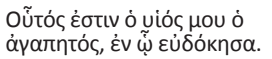 & 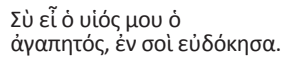 & 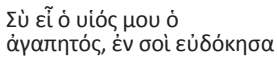 \\
\hline
\end{tabular}

contains a personal address, with 'You ( $\sigma \grave{)}$ are my Son' and 'in you (бoi) I rejoice', the voice in Matthew 3:22 makes a public announcement with an identification formula: ' $t$ this

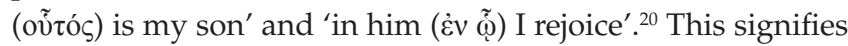
a public theophany and testimony to Jesus (Keener 1999:134; Luz 2007:143).

The divine sonship of Jesus has already been expressed by the narrator in Matthew 1:18-25 when the angel appeared to Joseph and told him that the child would be called 'Immanuel, which means 'God with us', and in the fulfilment quotation 'Out of Egypt I have called my son' (Mt 2:15). However, it is significant that this fact is now confirmed from heaven ${ }^{21}$ by God himself.

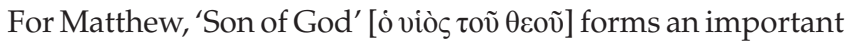
Christological title. Jesus is even recognised as the Son of God by the demons (Mt 8:29). In a hymn of jubilation, Jesus declares his unique relationship with the Father, which gives him unique authority (Mt 11:27). He demonstrates this in his authority over the weather (Mt 14:33). Jesus' disciples use this title on the lake (Mt 14:33), as does Peter in his confession (Mt 16:16). Jesus indirectly presents himself as the Son of God in the parable of the tenants (Mt 21:37). He is charged as such by the high priest and accepts it as such (Mt 26:63). He is recognised as the Son by the centurion (Mt 27:54). This recognition by the centurion is emphasised by supernatural events and confessions by the whole guard (Mt 27:40, 43, 54).

As a Messianic title, 'Son of God' was a pregnant title in Judaism and the ancient world in general to claim filial relationships with deities (Davies \& Allison 2004a:340). However, Jewish history was not unfamiliar with human beings called 'sons of God' (France 1998:295). In several cases, David or his successor was called the 'son of God' (2 Sam 7:14; Ps 2:7, 89:26-27). In the Wisdom literature, righteous and holy men were hailed as 'sons of God' (Ben Sira 4:10; Wis 2:16-18; Ps Sol 13:9).22 This development is echoed in the crucifixion scene, where passers-by, the chief priests, teachers of the law and elders use this title sarcastically to mock Jesus as one who claimed to be the 'Son of God' (Mt 27:40, 43).

It seems that Psalm 2:7 forms the most appropriate background to this divine announcement at Jesus' baptism. Psalm 2 was

20.In John 1:34, the Baptist recognises Jesus as the Son of God because of the descent of the Holy Spirit upon Jesus, without reference to the dove or the voice from heaven.

21.The opening words of the quotation in Matthew 12:18-21 have verbal resemblance to these divine words.

22.In Matthew, the followers of Jesus who submitted to the will of the Father would also be called 'sons of God' if they were to be peacemakers (Mt 5:9) and would love their enemies (Mt 5:45) used as an enthronement psalm. Eschatological Messianic expectations were later linked to this psalm (Keener 1999:135). The frequent use of Psalm 2:7 in the New Testament indicates how this hope of a Messiah from the line of David had developed towards the identification of Jesus as the expected Messiah and 'Son of God'.

In Matthew, this filial relationship is further emphasised by the numerous occasions of Jesus calling God his Father. In Matthew, Jesus refers to God as the Father some 44 times (e.g. Mt 11:27, 24:36, 28:19), compared to four in Mark and 17 in Luke. In these calls, Jesus differentiates between 'my Father' (Mt 11:27, 12:50) and 'your Father' (Mt 5:16, 48, 6:4, 6, $15,18,7: 11)$, emphasising the unique relationship and mutual knowledge between Jesus and the Father ${ }^{23}$ (Luz 2005:94).

The phrase 'the beloved' [o d $\alpha \gamma \alpha \pi \eta \tau$ ó $\varsigma$ qualifies 'the Son of

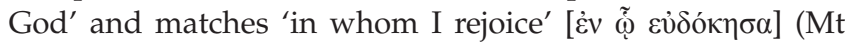
$3: 17)$. In Jewish traditions, God's special love for Israel is often expressed (e.g. Jub 31:15, 20). Rabbi Akiba $(3,14)$ comments: ' $[m]$ an is loved because he is made in the image of God ... Israel is loved especially because it is declared to them that they are called the children of God'. However, for Matthew, Jesus is the exceptional focus of God's love. 'Beloved' is used in Messianic context in the pseudepigraphical Jewish-Christian texts of the Ascension of Isaiah 1:4, 3:13 and the Testament of Benjamin 11. The designation 'in whom I

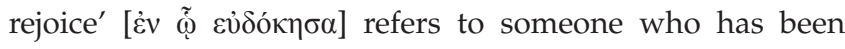
especially elected and associated with a strong emotional bond of love with the one that has been elected (Schrenk 1978:740). God's words confirm that Jesus is the recipient of his elective good pleasure. As elected Son, he has the mission, and as Messiah, he holds the appointment to the kingly office as judge and saviour. The result is that God's Spirit can rest upon him. Through him, God is 'with us' (Mt 1:23), and through him, he intends to execute his royal plan to save people from their sins (Mt 1:21).

This divine declaration in Matthew 3:17 is challenged by the devil. The devil also acknowledges Jesus as God's Son, but unlike God, he is not pleased with this identification. The devil addresses Jesus as the 'Son of God' in his temptation of Jesus in Matthew 4:3 and 6. Jesus does not succumb to the temptation of illustrating his unique sonship with spectacular acts. Instead, he confirms his sonship by submitting to the will of the Father (Turner 2008:34). Jesus proves himself as the 'Son of God' by living in obedience to the Father (Luz 2005:94). He exemplifies an ethical dimension to this expression (Mt 3:15, 4:1-11) and acts as the meek and humble Son (Mt 11:29). As the Son of God, he goes the way of passion in obedience to the Father (Mt 16:21).

\section{God's declaration at Jesus' transfiguration}

In Matthew 17:1-8, the scene is set as a visionary experience [ö $\propto \mu \alpha]$, which typically consists of the setting of the scene, 23. Matthew accounts that Jesus directly addresses his heavenly Father (Mt 11:25-26, 26:39, 42, 27:46) and encourages his disciples to do the same (Mt 6:9-13). 
the dream vision as such and the responses of the recipients of the vision (Dodson 2002:40). In the setting of the scene (Mt 17:1), Peter, James and John are named as the recipients; they are alone, the location is indicated and the time is specified. The dream vision and responses are twofold. The vision begins with the appearance of Moses and Elijah with the transfigured Jesus (Mt 17:3), which is followed by Peter's first reaction - his offer to build three huts ${ }^{24}$ (Mt 17:4). ${ }^{25}$ The dream vision then continues with the appearance of the cloud and the voice sounding from it (Mt 17:5), to which the disciples are overcome with fear (Mt 17:6).

In Jewish tradition, significant people received visions of the end of times, for example, Abraham (2 Esd 3:14) and Isaiah (Jn 12:41). In Jewish apocalyptics, there was the expectation that Moses and Elijah would appear together as part of the eschatological wind-up of history (cf. Dt Rab 3:17; 2 Esd 6:25-26). ${ }^{26}$ The Bible itself mentions the return of Elijah (Mal 4:4-5) and a prophet like Moses (Dt 18:15-19). Furthermore, the shining faces and clothes of dazzling white were regarded as typical of the end of times (2 Bar 51:1-6; Mt 13:43). The disciples would therefore probably have understood this vision as a preview of Jesus's parousia (Talbert 2010:209; Witherington III 2006:325), ${ }^{27}$ which would be the fulfilment of Jesus' promise in the previous chapter: 'I tell you the truth, some who are standing here will not taste death before they see the Son of Man coming in his kingdom' (Mt 16:28). The description of Jesus gleaming and shining like the sun furthermore echoes the description of Wisdom in the Wisdom of Solomon 7:26-29: '[s] he is the brightness of the everlasting light, the unspotted mirror of the power of God, and the image of his goodness'. Jesus is presented as God's Wisdom made manifest and the royal figure who promulgates and exercises wisdom, one to be listened to (Witherington III 2006:81).

This narrative reflects the typology of Moses on Mount Sinai, ${ }^{28}$ with Jesus going up the mountain and coming down again (Ex 24:12, 15-18, 34:3), the 6 days (Ex 24:16), the select group (Ex 24:1), the shining face or skin (Ex 34:29-35), a bright cloud (Ex 24:15-18,34:5), a voice from heaven (Ex 24:16) and the fear of the bystanders (Ex 34:29-30). Other than in Mark, Moses comes before Elijah. Matthew furthermore emphatically states that Moses and Elijah disappeared, leaving Jesus alone

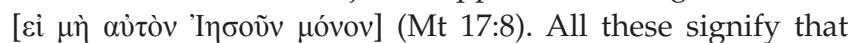
Matthew intends to characterise Jesus as the one who replaces

24.Peter's intention with the huts may have been to provide temporary shelter while they stayed on the mountain, there may have been more to this suggestion. In the they stayed on the mountain, there may have been more to this suggestion. In the ancient Egyptian and Mediterranean world, it was a common practice to
commemorate epiphanies by erecting temples or pillars (Talbert 2010:207). Jacob commemorate epiphanies by erecting temples or pillars (Talbert 2010:207). Jacob Beersheba after his vision (Gn 26:23-25).

25.Absent from Matthew's account is that Peter did not know what he was saying according to Mark.

26.Other ancient writers entertained similar expectations. According to the 2nd century AD diviner, Artemidorus Daldianus (Onir. 1:2), an ö $\rho \alpha \mu \alpha$, often pre-enacts a future event.

27.This transformation narrative correlates with 2 Peter 1:16-18 where transfiguration is regarded as proof of the power of Jesus and Parousia.

28.The narrative does not mention on which mountain the transfiguration took place. Traditionally, it was thought that it took place on Mount Tabor. However, if it happened close to Caesarea Philippi, it could have been on Mount Hermon.
TABLE 4: Synoptic comparison of the voice from the cloud.

\begin{tabular}{|c|c|c|}
\hline Matthew 17:5 & Mark 9:7 & Luke 9:34-35 \\
\hline 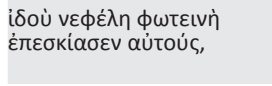 & 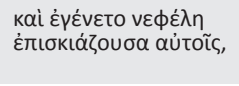 & 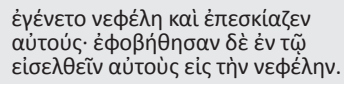 \\
\hline 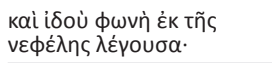 & 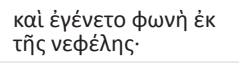 & 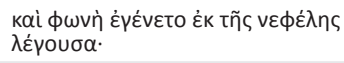 \\
\hline 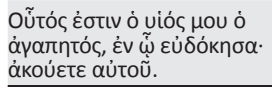 & 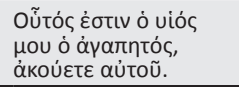 & 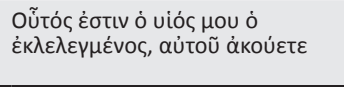 \\
\hline
\end{tabular}

Moses and Elijah, one who supersedes them..$^{29}$ Matthew's point is clear: Jesus transcends God's prophetic agents of the preceding stages of salvation history (Bauer 1992:358).

Table 4 presents the Synoptic parallel of the voice from heaven. When Matthew describes the appearance of the cloud, as Mark and Luke do, he paradoxically adds that the overshadowing cloud is bright [ $\varphi \omega \tau \varepsilon ı v \eta े]$. It is also Matthew alone who mentions that Jesus' face shone like the sun

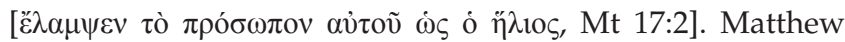
apparently has the Shekinah of the Lord in mind which filled the tabernacle in the wilderness (Ex 40:34-38) (Davies \& Allison 2004b:686; Keener 1999:439).

There are significant variations in the wording of the voice from heaven in the Synoptic Gospels: in Mark, the voice

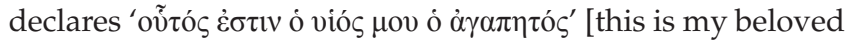

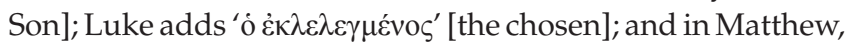
the wording correlates with the words of God's voice at the baptism of Jesus (Mt 3:17 et par.), 'oṽ

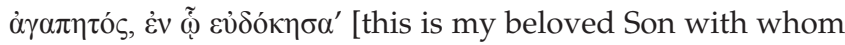
I am well pleased], which draw upon Psalm 2:7.

God once again confirms Jesus' identity as his Son, this time to the three disciples. It should be noted that this confirmation follows the prediction of Jesus' death, as it offsets the shock of the passion (Witherington III 2006:325). The disciples are assured that Jesus is still the Son of God, even though he will be killed. While their traditional Messianic hopes have been shattered, it would be replaced with better ones.

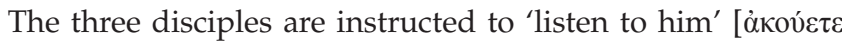

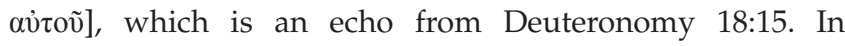
Deuteronomy, Yahweh promises to provide a prophet-like Moses to whom they must listen. There is no need to resort to divination, magic or necromancy to determine his will

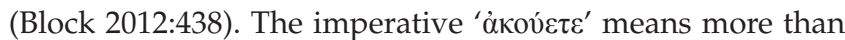
'hear', but to obey carefully (cf. the LXX Ex 6:12 and 2 Chr 28:11). A similar meaning of the word is found in Matthew 18:15-16, Luke 16:29 and 31, John 5:25 and 8:47 and Acts 28:28. After the departure of Moses and Elijah - the two great prophetic figures of the Old Testament - the disciples are instructed to now listen to Jesus, who supersedes them. Matthew's narrative would conclude with Jesus' announcement that all authority in heaven and on earth has been given to him and therefore he could instruct his disciples to teach all the nations what he has commanded them (Mt 28:18-20).

29.Jesus is addressed as 'beloved Son', a title which Moses and Elijah did not carry. 
It is only in Matthew's account that the disciples responded to this vision and voice from heaven by falling on their faces and being exceedingly fearful (Mt 17:6). ${ }^{30}$ This response of the disciples is expected from a theophany ${ }^{31}$ (Talbert 2010:207). In response to this fearful reaction, Jesus touches them and tells them to get up and not to be afraid (Mt 17:7). This action is similar to the response of heavenly visitors to people who feared their vision (cf. Rv 1:17b; Lk 1:30).

God's voice during Jesus' transfiguration provides further information of who Jesus truly is. As Son of God, he is the full manifestation of God's glory. He supersedes the great prophets of the past. God's people should listen to him.

\section{Conclusion}

Matthew portrays God only twice in direct action in the narrative, when he is invisible and perceived only as voice from heaven. When God speaks, he speaks of Jesus. Matthew directs all attention to Jesus. God's voice expresses the identity and authority of Jesus. He transfers his voice and authority to Jesus. Jesus comes into focus in his relation to God. He is the focus of God's love and plan for history. Jesus is not merely one of many prophets, but God's ultimate revelation. He characterises and authorises Jesus in relation to himself as his Father.

In the baptism scene, John objects to baptising Jesus. However, Jesus insists to fulfil all righteousness. Once baptised, the Father publically announces that Jesus is the Son of God, and Jesus is tempted by Satan to manifest his divine sonship in a display of worldly power. However, as this would defy the will of the Father, Jesus does not succumb. In Matthew 16:22, he is once again tempted to construe his sonship by avoiding the suffering of the cross. Once again God the Father confirms that Jesus is the Son of God. In the crucifixion scene, Jesus avoids the temptation of escaping from the cross, when those who pass by challenge him to come down from the cross if indeed he is the Son of God (Mt 27:40). When the chief priests, the teachers of the Law and the elders mockingly cry out, ' $[l]$ et God rescue Him now if He wants Him, ${ }^{32}$ for He said, "I am the Son of God"' (Mt 27:43), he remains obedient and fulfils righteousness even until his death on the cross.

Matthew's narrative clearly recounts Jesus' authority, an authority that not only points to him but eventually becomes his own. God attests that Jesus is greater and more authoritative than any of his previous messengers. As Jesus is 'God with us' from infancy (Mt 1:23), he

30.In Matthew 27:54, the centurion and those guarding with him at the cross of Jesus were also overcome by fear. Once again Jesus is confessed to be the Son of God. He is exalted in the state of humiliation.

31.Similar responses to theophanies are also found in Revelation 1:17, Numbers 22:31-35, Joshua 5:13-15 and 2 Maccabees 3:22-34.

32.The scorn of the chief priests, teachers of the Law and elders, 'If God wants Him

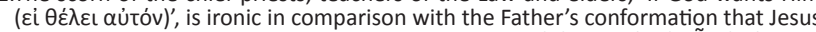

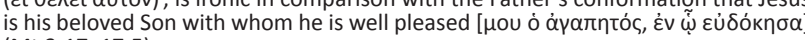
(Mt 3:17, 17:5). speaks throughout the Gospel with the voice of God. He appropriates and interprets God's words and overrides other interpretations.

God's testimony of Jesus in Matthew evokes response. A person cannot remain neutral or unaffected in the presence of Jesus. In the narrative, Jesus' disciples recognise him as the Son of God when he walks on the water and stills the wind, 'A $\lambda \eta \theta \tilde{\omega} \varsigma \theta \varepsilon \circ \tilde{v}$ viòs $\varepsilon \tilde{\tilde{i}}$ [Truly, you are the Son of God] (Mt 14:33), and when Jesus asks 'Who do you say I am?',

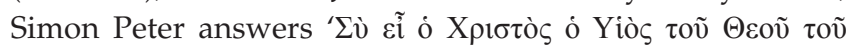
$\zeta \tilde{\omega} v \tau o \zeta^{\prime}$ [You are the Christ, the Son of the living God] (Mt 16:16). Conversely, in the crucifixion scene, those who pass by respond by insulting Jesus: '[c]ome down from the

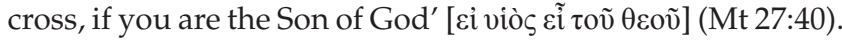
The chief priests and teachers of the Law in the narrative mocked him: '[l]et God rescue Him if God wants Him, for

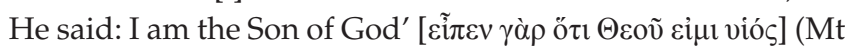
27:43). However, the centurion and those guarding Jesus, when observing the earthquake and the opening of tombs, recognise Jesus as the Son of God: 'A $A \eta \theta \tilde{\omega} \varsigma \theta \varepsilon \circ \tilde{v}$ viò $\tilde{\eta}^{\eta} v$ oṽ $\tau \varsigma^{\prime}$ ' [Truly the Son of God was this one] (Mt 27:54). The fact that Jesus dies as the Son of God demonstrates his absolute obedience to the will of the Father.

This obedience was well placed, as God raised him from the dead (Mt 28:1-10). The consequence is that all authority in heaven and on earth is given to him and that his disciples have to adhere to his great commission (Mt 28:18), as God has previously declared that his disciples should listen to him (Mt 17:5). With his all-inclusive authority, Jesus continues to be with his disciples always to the very end of the age (Mt 28:20). Jesus' authority comes from God. It does not only point to him, but it eventually becomes his own.

\section{Acknowledgements Competing interests}

The author declares that no competing interests exist.

\section{Author(s) contributions}

I declare that I am the sole author of this research article.

\section{Ethical consideration}

This article followed all ethical standards for a research without direct contact with human or animal subjects.

\section{Funding information}

This research received no specific grant from any funding agency in the public, commercial or not-for-profit sectors.

\section{Data availability statement}

Data sharing is not applicable to this article as no new data were created or analysed in this study. 


\section{Disclaimer}

The views and opinions expressed in this article are those of the author and do not necessarily reflect the official policy or position of any affiliated agency of the author.

\section{References}

Allert, C.D., 2002, Revelation, truth, canon and interpretation: Studies in Justin Martyr's dialogue with Trypho, Leiden, Brill.

Anderson, J.C., 1994, Matthew's narrative web; over and over again, Sheffield Academic Press, Sheffield.

Bauer, D.R., 1992, 'The major characters of Matthew's story: Their function and significance', Interpretation 46(4), 357-367.

Block, D.I., 2012, The NIV application commentary on Deuteronomy, Zondervan, Grand Rapids, MI.

Burnett, F.W., 1993, 'Characterization and reader construction of characters in the Gospels', in E.S. Malbon \& A. Berlin (eds.), Semeia 63: Characterization in Biblical literature, pp. 1-28, Scholars, Atlanta, GA.

Carter, W., 1998, 'Narrative/literary approaches to Matthean theology: The "Reign of the Heavens" as an example (Matt. 4:17-5:12)', Journal for the Study of the New Testament 20(67), 3-27.

Chatman, S., 1978, Story and discourse: Narrative structure in fiction and film, Cornell University, New York.

Culpepper, R.A., 1984, 'Story and history in the Gospels', Review and Expositor 81(3), 467-478.

Davies, W.D. \& Allison, D.C., 2004a, Matthew 1-7, International Critical Commentary, vol. 1, T \& T Clark, London.

Davies, W.D. \& Allison, D.C., 2004b, Matthew 8-18, International Critical Commentary, vol. 2, T \& T Clark, London.

Dodson, D., 2002, 'Dreams, the ancient novel, and the Gospel of Matthew: An intertextual study', Perspectives in Religious Studies 29(1), 39-52.

Edwards, R.A., 1997, Matthew's narrative portraits of disciples, Trinity Press International, Harrisburg.

Egan, K., 1978, 'What is a plot?', New Literary History 9(2), 455-473.
France, R.T., 1998, Matthew evangelist and teacher. New Testament profiles, Intervarsity Press, Downers Grove, IL.

Genette, G., 1980, Narrative discourse: An essay in method, Cornell University, Ithaca. Greimas, A.J., [1966] 1983, Structural semantics: An attempt at a method, transl. D. McDowell, R. Schleifer \& A. Velie, University of Nebraska Press, Lincoln, NE.

Hays, M.H., 2013, 'Towards a faithful criticism', in C.M. Hays \& C.B. Ansbury (eds.) Evangelical faith and the challenge of historical criticism, pp. 1-23, Baker, Grand Rapids, MI.

Keener, G.S., 1999, A commentary on the gospel of Matthew, Eerdmans, Grand Rapids, MI.

Kingsbury, J.D., 1986, Matthew as story, Fortress Press, Philadelphia, PA

Knowles, M.P., 2008, 'Plotting Jesus: Characterization, identity and the voice of God in Matthew's Gospel', in T.R. Hatina (ed.), Biblical interpretation in early Christian Gospels, vol. 2, The Gospel of Matthew, T \& T Clark, London.

Luz, U., 2005, Studies in Matthew, Eerdmans, Grand Rapids, MI.

Luz, U., 2007, Matthew 1-7, Fortress Press, Minneapolis, MN.

Menken, M.J.J., 2004, Matthew's Bible. The Old Testament text of the Evangelist, University Press, Leuven.

Powell, M.A., 1990, What is narrative criticism?, Fortress Press, Minneapolis, MN.

Powell, M.A., 1992, 'The plot and subplots of Matthew's Gospel', New Testament Studies 38(2), 187-204.

Powell, M.A., 2009, 'Literary approaches and the Gospel of Matthew', in M.A. Powel (ed.), Methods for Matthew, pp. 44-82, Cambridge University Press, Cambridge.

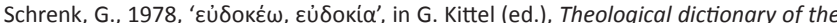
New Testament, vol. II, pp. 738-751, Eerdmans, Grand Rapids, MI.

Talbert, C.H., 2010, Matthew, Baker Academic, Grand Rapids, MI.

Tolmie, D.F., 1999, Narratology and Biblical narratives: A practical guide, Wipf \& Stock, Eugene, OR.

Turner, D.L., 2008 Matthew, Baker Academic, Ada, MI.

Versteeg, J., 1992, Evangelie in viervoud. Een karakteristiek van de vier evangeliën, Kok, Kampen.

Viljoen, F.P., 2018, 'Reading Matthew as a historical narrative', In die Skriflig 52(1), a2390. https://doi.org/10.4102/ids.v52i1.2390

Weren, W.J.C., 2014, Studies in Matthew's Gospel, literary design, intertextuality, and social setting, Brill, Leiden. 